\title{
Cemal Süreya em cinco poemas
}

\author{
Marco Syrayama de Pinto
}

Cemal Süreya (Cemalettin Seber, 1931, Erzincan - 9 de janeiro, 1990, Istambul), foi um poeta e escritor turco, pertencente à etnia zaza (irânica). Após o Massacre de Dersim que ocorreu em 1937, em Dersim (localizada na província de Tunceli), no leste da Turquia, sua família foi deportada para a cidade de Bilecik, na Anatólia ocidental. O massacre foi uma reação militarizada do governo de İsmet İnönü (sucessor de Atatürk) contra a rebelião liderada por Seyid Rıza, chefe da tribo Abbasuşağı, que se insurgira contra o governo. Esse desastre teve um impacto significativo nos poemas de Süreya.

Formado em Ciências Políticas pela Universidade de Ancara, Süreya é um nobre representante da Segunda Nova Geração (os Ikinci Yeni) da poesia turca, que foi um movimento abstrato, parcialmente inspirado em movimentos ocidentais, como o dadaísmo e o surrealismo, e que foi caracterizado pelo uso de linguagem inesperada, imagens complexas e associação de ideias. Surgiu como reação ao movimento mais popular denominado Garip ("estranho", em turco) e aos aspectos sociais típicos da poesia de Nazım Hikmet Rân; além disso, caracteriza-se pelo uso da língua vernácula e por elementos surrealistas. Entre seus representantes mais famosos estão Orhan Veli, Oktay Rifat e Melih Cevdet Anday. 
Marco Syrayama de Pinto. Cemal Süreya em cinco poemas

Cemal (pronuncia-se /djemal/) é um importante representante da literatura turca moderna - poeta revolucionário, ensaísta e prolífico tradutor. Ele também atuou como inspetor no Ministério de Finanças e como diretor da Casa de Moeda de Istambul. Ademais, foi editor de influentes revistas literárias e recebeu vários prêmios importantes na Turquia.

\section{Referência}

SÜREYA, Cemal. Sevda Sözleri: Bütün Şiirleri. İstanbul: Yap1 Kredi Yayınları, 2007, pp. 13, 26, 208, 241, 302.

\section{Eliyle, Samanyolu'na}

Yaşadım, Tanrım,

Yarım ve uluorta,

Bir dahaki hayatta,

Varsa öyle bir hayat,

Şiir yazar mıydım,

Bilmiyorum.

Ama kadınlar, Tanrım,

Öyle sevdim ki onları,

Gelecek sefer

Dünyaya

Kadın olarak gelirsem,

Eşcinsel olurum. 


\section{De 1994 à Via Láctea}

Eu vivi, meu Deus,

Pela metade e de maneira frívola,

Na outra vida,

Se é que existe tal vida,

Serei poeta?

Eu não sei.

Mas eu amei as mulheres

de tal maneira, meu Deus,

que a próxima vez,

se nascer mulher,

serei lésbica. 
Marco Syrayama de Pinto. Cemal Süreya em cinco poemas

\section{Sizin hiç babanız öldü mü?}

Sizin hiç babanız öldü mü?

Benim bir kere öldü kör oldum

Yıkadılar aldılar götürdüler

Babamdan ummazdım bunu kör oldum

Siz hiç hamama gittiniz mi?

Ben gittim lambanın biri söndü

Gözümün biri söndü kör oldum

Tepede bir gökyüzü vardı yuvarlak

Şöylelemesine maviydi kör oldum

Taşlara gelince hamam taşlarına

Taşlar pırıl pırıldı ayna gibiydi

Taşlarda yüzümün yarısını gördüm

Bir şey gibiydi bir şey gibi kötü

Yüzümden ummazdım bunu kör oldum

Siz hiç sabunluyken ağladınız mı?

(1953) 


\section{Você já perdeu o seu pai?}

Você já perdeu o seu pai?

$\mathrm{O}$ meu morreu uma vez e eu fiquei cego.

Lavaram-no e o levaram embora.

Eu não esperava isso do meu pai: eu fiquei cego

Você já foi a um hamam?

Eu já; uma lâmpada apagou

Um dos meus olhos apagou e eu fiquei cego

No alto havia um céu redondo

Era tão azul que eu fiquei cego

Já as pedras, as pedras do hamam

As pedras estavam brilhando como um espelho

E eu vi a metade do meu rosto nas pedras

Era como algo, tão ruim quanto algo

Eu não esperava isso do meu rosto: eu fiquei cego

Você já chorou enquanto se ensaboava?

(1953) 
Marco Syrayama de Pinto. Cemal Süreya em cinco poemas

\section{İki Kalp}

İki kalp arasında en kisa yol:

Birbirine uzanmış ve zaman zaman

Ancak parmak uçlarıyla değebilen

İki kol.

Merdivenlerin oraya koşuyorum,

Beklemek gövde kazanması zamanın;

Çok erken gelmişim seni bulamıyorum,

Bir şeyin provası yapıllyor sanki.

Kuşlar toplanmışlar göçüyorlar

Keşke yalnız bunun için sevseydim seni.

\section{Dois corações}

O caminho mais curto entre dois corações:

Estendidos, e que às vezes,

Conseguem se tocar só com a ponta dos dedos,

São os braços.

Estou correndo para as escadas,

Esperar é a encarnação do tempo;

Cheguei muito cedo, não te encontrei,

É como se algo estivesse sendo ensaiado.

Os pássaros se juntaram e estão migrando

Ah se eu tivesse te amado somente por isso. 


\section{Üstü Kalsın}

Ölüyorum tanrım

Bu da oldu işte.

Her ölüm erken ölümdür

Biliyorum tanrım.

Ama, ayrıca, aldığın şu hayat

Fena değildir...

Üstü kalsın...

(Yeni Yaprak, sayl: 13, Ocak 1990)

\section{Fique com o troco}

Estou morrendo, meu Deus

Isso aconteceu também.

Toda morte é uma morte prematura

Eu sei, meu Deus.

Mas, além disso, esta vida que você está levando

Não é tão ruim...

Fique com o troco...

(Yeni Yaprak, número 13, janeiro de 1990) 
Marco Syrayama de Pinto. Cemal Süreya em cinco poemas

\section{Önceleyin}

Önce bir ellerin vardı yalnızlığımla benim aramda

Sonra birden kapılar açılıverdi ardına kadar

Sonra yüzün onun ardından gözlerin dudakların

Sonra her şey çıkıp geldi

Bir korkusuzluk aldı yürüdü çevremizde

Sen çıkardın utancını duvara astın

Ben masanın üstüne koydum kuralları

Her şey işte böyle oldu önce

(1954)

\section{Primeiro}

Primeiro havia só suas mãos entre mim e minha solidão

Depois, de repente, as portas se escancararam

Depois seu rosto, seus olhos, seus lábios

E depois tudo apareceu por inteiro

Um destemor envolveu-nos

Você tirou sua vergonha e a pendurou na parede

E eu coloquei as regras na mesa

Tudo aconteceu assim primeiro

(1954) 